\title{
GENESIS OF SPATIOLOGY
}

\section{WORKS OF GYULA HAJNÓCZI ON THE FIELD OF ARCHITECTURAL THEORY OF SPACE ${ }^{\#}$}

\begin{abstract}
LÁSZLÓ DARAGÓ
DLA, associate professor. Department of History of Architecture and Monument Preservation, BME K II. 82, Mủegyetem rkp. 3, H-1111 Budapest, Hungary. Phone: (+36-1) 463-1330. E-mail: darago@eptort.bme.hu

We can find the sprouts of the architectural approach of space in ancient Greek Philosophy. The process lasts from the Pythagorean notion (kenon) - which is the emptiness between the numbers - to the definition of space by St Augustine, where he determines the forming of space as the main role of architecture. The enquiry regarding architectural approach of space intensified after the Second World War - Hajnóczi joined into this discourse with his works on the field of spatial theory in the 1960's. He intended to create a unified framework for the different approaches of space from different fields of science. This common range of interpretation is deriving from the analytic understanding of space - that is Spatiology. Overviewing Hajnóczi's theoretical works we will try to show the evolution of his thoughts and will try to identify the antecedents of his theoretical structures in the works of contemporary thinkers. In his academic doctorate dissertation in 1977 with the analytic approach he subdivided the architectural space into its elemental spatial relations generated by the constructional objects and then he has attempted to give the quantitative and also the qualitative understanding of them. In his Genesis - as the last accord of his oeuvre - he tried to understand the particular elements of this system and also build an intelligent whole of them again.
\end{abstract}

Keywords: Gyula Hajnóczi, theory of architecture, theory of space, Spatiology, genesis

"Thus, the built environment is not simply a physical environment, but an objectified form of human behaviour, a summary of life moments realized by the specific means of architecture. In which the Self and the community, the past and the present are summed up. If all this is true, then the question rightly arises: how the many things that dead material absorbed into itself when it came to life as a building were created."

Hajnóczi, Gyula: "The Genesis of Architectural Space"1

As a student of architecture, I had the fortune to get acquainted with Professor Hajnóczi in the course of his lectures upon history of architecture. His charismatic figure grabbed us all at once. His precise and artistic sentences provided suggestive content and at the same time perfect examples of finely composed forms of verbal constructions. He saturated the auditorium with his heavy texts - we all could feel

\# This work was supported by the National Cultural Fund of Hungary (NKA) under Grant Number $101108 / 547$.

${ }^{1}$ Hajnóczi J. Gyula: Az építészeti tér genezise. Part I-IV. Iskolakultúra 2 (1992) 22. 2-10; 2 (1992) $23-24$. 10-21; 3 (1993) 1. 20-33; 3 (1993) 5. 35-43. https://ojs.bibl.u-szeged.hu/index.php/iskolakultura/article/view/ 28788 (Accessed 7 December 2020.) 
the presence of science. In spite of all this pathos, these sentences - filled with a lot of scientific foreign words - sounded so natural in his veiled voice as if that deep issue had been the simplest thing on earth. HUMANITY was projected through the words - the Renaissance Man... But to understand the scale of his individuum one needed to mature first. I met the published version of his grand theoretical work: Vallum and Intervallum, dealing with architectural space, only at the end of my studies. I was spellbound by the crystallised way he tied the thoughts one to another; and I felt I really had found what I had come to this school for: science that gives sense to the existence of homo architectus. Thus I could have an insight into the depth of the issues, I could step into the sanctuary of the creation of space. This time my intention is to introduce - in a sketchy way - his theoretical works upon architectural space... in other words: to outline the genesis of "The Genesis of Architectural Space" (Az épitészeti tér genezise).

If we take a look at the published oeuvre of Hajnóczi we can state that there are 22 pieces dealing with architectural theory out of 87. As far as their extant is concerned also the list of the theoretical works contains large corpuses like his doctorate dissertation for the Academic membership, the Prolegomena and his last corpus: Appendix, which can be a match for his great historic pieces like his Textbook upon the history of architecture in antiquity. If we compare it with his other numerous activities (he was active as an architect and expert of monuments preservation, an archaeologist of antiquity, a historian of architecture), we can state that this specific part of his activity covers almost $1 / 4$ of his life - thus it can highlight for us his commitment towards the issue. Moreover, if we add to all this the great number of his works dealing with architectural space (15 items) than we can feel his devotion towards the base material of architecture - the space.

In western culture, the first architectural approach of space can be traced back to ancient Greek thinkers. In Hajnóczi's great summary about the history of theory of architecture ${ }^{2}$ he states that the first definition of the entity in-between was determined by the Pythagorean thinkers, who named the "emptiness" between the numbers in

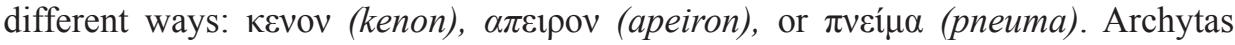
makes a more "geometrical" definition that has a closer meaning to architecture in the $4^{\text {th }} \mathrm{c}$. BC, distinguishing the mass or object $\varsigma$ o $\mu \alpha$ (soma) and the place that is occupied by it: $\tau$ o $\pi \mathrm{o} \varsigma$ (topos). The work of Euclid helps a lot to describe the characters of space. But the most direct correspondence between architecture and space was fixed by St Augustine the Great. He stated that the main elements of architecture are not the definition of structures and the borders of space, but of the space itself. Since that time on, the debate about architectural space has been open. That was heated up after the Second World War, mainly in the 1960's, when a multilateral scientific approach became relevant also in architecture. That was what Hajnóczi sensed and felt the urge to join this dispute with a strong decision to integrate a common field for all approaches.

\footnotetext{
${ }^{2}$ Hajnóczi J. Gyula: Az épitészetelmélet története. Manuscript 1990. 7.
} 
His first work upon space theory was born in the $7^{\text {th }}$ year of his publication activity - in 1959: Concept of Space in Fine Arts and Architecture. ${ }^{3} \mathrm{He}$ is interested in the common attitude of seeing the world in the case of creative arts, focusing on a special approach, which was the main interest of the generation of architects right after the Second World War. His start-up showed that even those arts that are using only two dimensions can express their relation towards the three-dimensional space. “... as the fine arts and also architecture need space - that is the medium where they unfold and exist - so we have to grab and explain their relation to it in some way...." "4his thesis was verified by means of the examples of ancient Egyptian art: “... Egyptian wall paintings, statues, and buildings are the children of the same special approach despite of their differences in their genre: the drawing constructed according to the canon of the largest surfaces, the figure exposed in a frontal position, and the linear unfolding of the architectural space - they are all variations of the same theme played on different instruments. " He has showed that a two-dimensional drawing mixes (condenses) the special views in a way like a statue that has only two main visions, and also in the case of architectural spaces we can move only along the lines running in two ways - parallel the frontal and lateral unfolding of sculptures. He states that the basic form of the Egyptian architectural space is the "two dimensional space" - the dromos, and finally summarizes with a beautiful analogy: “... the history of the different districts was catenated by the gigantic dromos of the life-giving River Nile, which was waving and pulsing almost isolated from the rest of the world, the path of the sun was also a linear road, just as the human life leading to death and for the privileged ones also coming backwards from eternity on the same way. "6

$* * *$

The article titled "The Basic Tendency of Forming Space" followed the first one two years later. On the one hand, it is spreading the basic ideas about Greek art but on the other hand it analyses the wider range of buildings on the quest of finding the basic tendency of space forming. He defines it as follows: “... we understand it as a space organizing capability realized in forming and connecting of spaces." 8 Meanwhile, he puts his foot down in the questioned matter - defining the space creation aspect as prior to structural determinism. In his statement the aim of the architectural creation is the space itself and not the structure. In 1961 he entered into long explanations of why he was dealing with a "non-existing" substance - the space, as

${ }^{3}$ Hajnóczi J. Gyula: Térszemlélet a képzőművészetben és az építészetben. Müvészettörténeti Értesitő (1959) 2-3. 97-100.

${ }^{4}$ Hajnóczi 1959. 97. (All quotations have been translated by the author.)

${ }^{5}$ Hajnóczi 1959. 97.

${ }^{6}$ Hajnóczi 1959. 100.

${ }^{7}$ Hajnóczi J. Gyula: A térformálás alaptendenciája. Épités- és Közlekedéstudományi Közlemények 5 (1961) 3. 345-360.

${ }^{8}$ Hajnóczi 1961. 347. 

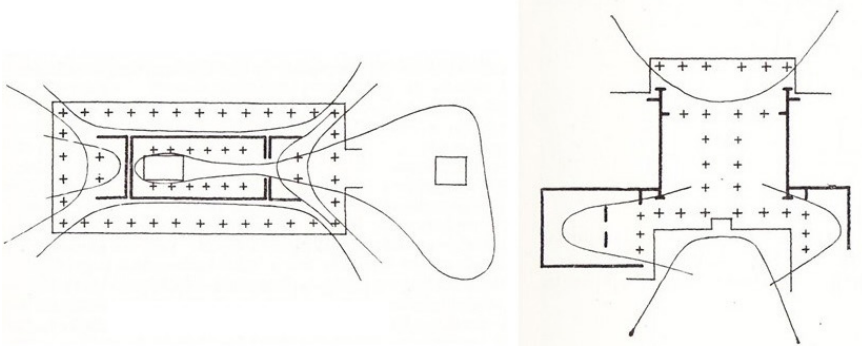

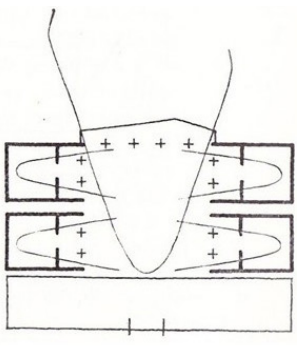

Figure 1. The illustrations of the U-shape space opened up on one side from the article of Hajnóczi from 1961. 1. Temple of Zeus, Olympia. 2. Propylaea, Athens. 3. Greek dwelling house made of megarons, Larisa. Source: Hajnóczi, Gyula: A térformálás alaptendenciája.

Épités- és Közlekedéstudományi Közlemények 5 (1961) 3. 345-360.

if he had to prevent himself from the accusation of idealism. That was not welcomed by the hard-liner politically determined ideology of scientific socialism grown on the bases of materialism. "According to which component of the general aspects prevails: the temporal or the spatial one, the aspect of space bound to different eras is changing, producing a great variety of the history of art." This thesis is detailed in the following sections.

As an aspect of space similar to the one in architecture can be pointed out in fine arts too, so can we detect it in the architectural details as well. By means of this statement he gives the criticism of the single-sided understanding of Greek architecture - which is over-emphasizing its sculptural character. He offers a U-shaped space composition instead - as base-type - unfolding from the megaron: a space-experience opening from the interior towards the exterior. He proves the existence of this base-type in the case of numerous building types, from the peripteros temples through the stoa-forms, and theatre-forms and different public building-forms to different versions of dwelling houses (Fig. 1).

The statement that even the architectural details can tell of particular special aspects is proved by the phenomena that in the case of eras that are oriented mostly towards the space the details are wasted, simplified or reduced to be more plain-like, whereas the eras oriented mostly towards objects are emphasizing the details - first and foremost their special sculptural character. "The architectural space and the spatial value of the architectonic details are in correlation with each other, and it is very probable that in times of space-focused forming (when general thinking in space compositions dominated) when the space is striving to monopoly, details are likely to be wasted, almost creeping back under the pressure of space (Byzantine and Late Gothic era). The Hellen era is not like this. The pieces of art and architecture want to maintain a constant connection with the external spaces, which do not waste, but

\footnotetext{
${ }^{9}$ Hajnóczi 1961. 351.
} 
- on the contrary - require articulation, thus the spatiality and the mass-focused character of details are emphasized." 10

Like the River Nile had an effect on the spatial aspect (on its axial character) prevailing in Ancient Egypt, as a kind of basic experience of geographical sense of position, the geographical determination of the Greeks is deriving from their existence along seashores. This is also a linear determination, but the attention is unfolding perpendicular to this line. The ideology of the Greeks is based upon this border-line situation: between the internal world of the individuum and the external world containing their gods as well - between the specific and the general, between the mortal and eternal and between the moment-borne and the timeless. It is worth hearing his own words, as these are precise but poetic at the same time: "... and some players are not closing themselves into the physiognomy of specific subjects... but are escaping into a half timeless and half real stature... [that is why] we can feel even now that beauty is something what the Greeks have formed and said to be that." 11

The secondary result of this work is fixing a nomenclature, as a kind of adaptation of environmental psychologic notions into architectural theory: the system of the temporal and spatial sense of position, which together are forming the spatial approach (outlook on space). In this system, the spatial sense of position can be subdivided into Geographical, Natural, and Physiological components, whereas the temporal sense of position contains Chronological, Historical and Social elements. This represents Hajnóczi's sensitivity towards the contemporary scientific tendencies focusing on the human aspects.

The crown of this theoretical system is his candidate dissertation in 1965: "The Development of Spatial Approach (viewpoint) in the Architecture of Antiquity" (in Hungarian: A térszemlélet fejlödése az ókor épitészetében), where these ideas probe the entire era of antiquity, and their veracity is proven many times.

The insight and the analysis of ongoing international researches upon the theme of architectural space is executed in two representative articles on the critical method: from Riegl to Giedion and from Giedion to Norberg-Schulz. The first was issued in 1967, entitled "The Evaluation of the Forming of Architectural Space from Riegl to Giedion." 12 He draws the lesson condensed into four points: "1) The double feature of architecture should be meant that soma and space are ever existing characters of it and their perception was not born in a chronological order. 2) The analysis should extend to wide range of building types, and should not be limited only to the chosen ones. 3) The analysis should not be based upon the actual forms of the buildings -

\footnotetext{
${ }^{10}$ Hajnóczi 1961. 356.

${ }^{11}$ Hajnóczi 1961. 359.

${ }^{12}$ Hajnóczi Gyula: Az építészeti téralakítás értékelése Riegltől Giedionig. Épitôipari és Közlekedési Müszaki Egyetem Tudományos Közleményei 13 (1967) 3-4. 131-135.
} 
these are the direct dependencies of function and structure - but rather derived from that capability which do organise the objective and non-objective parts, structural elements and usable spaces of the buildings. 4) This phenomenon, which is an independent tendency from building material, from structure and function, should be recognised as the projection of the ideology of the actual period of time, in accordance with other cultural achievements. "13

These sentences can be regarded as scientific postulates for his spatial researches. Looking into the cited works we can have a good insight into the reasons. In the work of Alois Riegl about the late Roman applied art (Spätrömische Kunstindustrie) he put into words - as a spin-off - that the Roman architecture has given birth to the interior architectural space - in the sense of the word as we use it.

Riegl shows three different stages of the development of antiquity based upon: 1) the pyramid, 2) the peripteros and 3) the Pantheon - 1) a creation method that is having indisposition for sensing spatial relations: that is tactisch, based upon tactility; 2) the intermediate method: tactisch-optisch, based upon tactility and visibility; 3 ) and a method based purely upon visibility: optisch. Hajnóczi admits the existence of the tendency, but rejects its exclusivity, opposing Riegl's description of the process as an evolution of qualities that is heading from material towards non-material methods, whereas architecture owns both aspects in all periods of time. (Only the proportion is changing between them, and sometimes the process is turning vice-versa, and he gives some examples for it.) Hajnóczi confesses to the co-ordinate values of soma and space.

"So, the building has an objectified part: its shell, and a non-objectified part: its delimited space. [...] This double feature of architecture is its eternal character, almost its genre determinant, and the history of architecture is no other than the sequence of changing of the relationship between them." 14

In the work of Sigfried Giedion - Space Time and Architecture - in 1941, Hajnóczi recognises Einstein's approach to space and time and regards it as a successful attempt for the contemporary adaptation of physical notions into architectural theories. He regards this work as the first good summary of modern architecture, inheriting Wölfflin's sensitive abilities of complex analysing and the viewpoint from cultural history of J. Burckhart.

The book of Bruno Zevi from 1957 - Architecture as Space - is a comprehensive work about the history of architecture. He changes the viewpoint of the descriptions: history becomes the "story of spaces." Hajnóczi is pleased that the forming of spaces is determined by the content of the space, which is a human factor: "it is given by the man [social content] who is living in it, who is acting in it, who is experiencing it with the entire sum of his/her psycho-physiological abilities. " 15 But this is a changing factor, and absorbs almost every aspect of social life from economics to politics,

\footnotetext{
${ }^{13}$ Hajnóczi 1967. 131.

${ }^{14}$ Hajnóczi 1967. 131-132.

${ }^{15}$ Hajnóczi 1967. 133-134.
} 
from philosophy to technics, and from psychology to arts. So, every aspect which has a capacity to determine space is taken into consideration. For Hajnóczi's disciplined scientific way of thinking it is too much. According to him: this multilateral viewpoint cannot lead to a coherent system. And at the end there is no theory behind the described phenomena, and nobody knows what the author's opinion is about what drives the development of the spatial approach. Though Zevi's statements can hide some truth for Hajnóczi about the human scaled Greek architecture, the static space of Roman architecture, the early Christian's closeness to humans, the stresses of the byzantine space, the extremely proportioned flowing of the Gothic one, the massive and mathematical Renaissance, the movement of the baroque, and the urban context of the historicism, and finally the organic character of modernism, but it is not a theory, just a sum of interesting approaches.

Sigfried Giedion issued a book in 1964: The Beginnings of Architecture. It is also an analysis of the history of architecture. But this time Giedion, leaving his closest field of interest - modernism - creates an extremely simplified system. He describes only three stages of development: 1) sculptural objects in an infinite space (from zikkurat to the Acropolis); 2) from the late antic harbour-like, hollowed-out space to the end of the $18^{\text {th }} \mathrm{c} . ; 3$ ) and finally the $19^{\text {th }}-20^{\text {th }} \mathrm{c}$.: the synthesis of the two. In order to secure his system from collapsing he had to separate architecture from other arts. The explanation is: architecture cannot react as fast as the others. This system is rougher when compared to Riegl's work, and it remains much further from the evolution of spatial approach.

Probably the most entire critical overview of the special literature dealing with the architectural space of the few decades after the Second World War is the article issued in 1977 entitled "The Interpretation of Architectural Space from Giedion to Norberg-Schulz" ${ }^{16}$ It was the published first chapter of his academic doctorate dissertation - a kind of history of the corresponding researches. This is the recapitulation of a ten year long scientific research not only based on collecting data, but also on the multi-layered knowledge crystallized from his creative experiences and praxis. While a similar article from 1967 was a brief outlook and interpretation of the contemporary international specialist literature, this one is a much detailed analysis of the achievements of other scientists in the light of his own experiences of scientific research. As in the first article we can feel a kind of dissatisfaction (sometimes frustration that might have been deriving from his higher expectations) in his remarks, ten years later these remarks have turned to be well established, definite judgements. Even his writing style has cleared a lot - his sentences are shorter, slimmer and are more categorical.

\footnotetext{
${ }^{16}$ Hajnóczi J. Gyula: Az építészeti tér értelmezése Giediontól Norberg-Schulzig. Épités- Épitészettudomány 9 (1977) 4. 331-350.
} 
There is not even a trace of any uncertainty and a self-assuring compulsion. His theme - the space - is not regarded as a suspiciously idealistic approach to architecture any more - by the year 1977 it was accepted even in this part of Europe to take this issue as the subject of research - without ideological aftermath. (It was very characteristic to the sensitive - politically controlled - situation earlier, that in his article issued in 1967 entitled "Space and Ideas", which is the publication of his candidate dissertation from 1965 in English, he had to mask his major theme behind a striking conceit: naming the space as the subconscious of architecture - expressing its secondary but at the same time determining role.)

"So, it is almost natural that the approach to architecture from the side of space seems to be - even today - at least uncertain if not unpassable in the eyes of many. I am not referring primarily to those who are not able to step over the -I am brave enough to mark it in this context: positivistic - framework of material, technics and technology, but to those, who regard this kind of experimentation as a late flourishing of already passed ideologies..."17

Analysing the researches after the Second World War he begins with Bruno Zevi. It is interesting to observe the difference in his tones in describing this work ten years later. The cheering of Zevi's decision to understand architecture as the art of space is constant, but while he had accepted in 1967 the multi-lateral viewpoint for describing the approach (outlook) of space in different periods of time, his criticism is harder in 1977. Let us compare the two attitudes. In 1967: "The acknowledging of the diversity of viewpoints will bear uncertainty, because the opinion of the author in the question of the development of space-forming remains unveiled. "18 In 1977 his opinion is more distinct and also gives, undoubtedly, a judgement: "In spite of the fact that the appropriateness of his findings cannot be doubted we have to evaluate this work as an interpretation - characteristic also to other thinkers - of the issue with a naive realism." If we look behind the politeness of the words, Hajnóczi's opinion is rather an oppressing verdict. Supporting his opinion he has not just articulated his doubts in connection with the incoherence of the system, but he has pointed out mercilessly particular mistakes where this heterogeneous system leads to wrong recognitions (as in the case of the statue-like character of the Greek architecture).

The work of Siegfried Giedion in this field (The Beginnings of Architecture [1957] and its unfinished antecedents, the series of The Eternal Present) is taken by Hajnóczi as the far side of the issue: "[The works of S. Giedion] ... can be characterised by a far simplified ultimate understanding of the phenomenon of space instead of the multilateral viewpoint..." 19 This time we can see a more detailed evaluating of the theory in which Hajnóczi stamps the parallelism between the space concept of Einstein and the modern approach of architectural space as just a conceit that speaks

\footnotetext{
${ }^{17}$ Hajnóczi 1977. 332. He gives a good reason of refuting the charge of outdatedness when referring to the contemporary work of S. Giedion, who inspired the idea of handling the space as the subconscious of architecture.

${ }^{18}$ Hajnóczi 1967. 134.

${ }^{19}$ Hajnóczi 1977. 335.
} 
about nothing in vain. In the eyes of Hajnóczi, Giedion falls back to the same trap where Riegl had fallen in: the chronologic sequence of the focus on mass and space - emphasizing the importance of the mass concept. This simplified description of the space - as the development from the sculptural objects passing through the hollowed-out space reaching the combination of the two - is such a rough resolution image for Hajnóczi's scientific eyes that he begins to provide excuses in the context as, for example: in the late period of his career, Giedion - leaving his particular field of interest (modernism) - began the description of historic architectural spaces. Finally, the greatest problem in this theory is again in the variety of the causal system: the anomalies within the very few categories force Giedion to refer to heterogeneous reasons to find explanations.

The work of Elias Cornellé calls the attention of Hajnóczi to the problem of genesis of space. In his concept the traditional basic phenomena - mass-space - was changed to the pair of spatial ones: exterior and interior, or in general: outer and inner. (In this approach, the mass and the space are handled as complementary - immanent - elements of architecture.) The different stages of the generation of architectural space are pushed into prehistoric times. The first stage was the outdoor enclosed space, than the real interior as the special version of the first and the house possessing both interior and exterior characters. Hajnóczi is pleased with the spatial focus of the development.

On the bases of this work, Ir. Pieter Dijkema continued the observations from Cornelle's focus on ancient times towards the whole history of architecture. In his 1960 work he organizes the system according to human vulnerability that drives human needs. The latter is the generator of human space. The very expressing drawings and figures in this work prove their important role in illustrating ideas. Maybe this convinces Hajnóczi to use even more expressing drawings in his Prolegomena.

Maybe one of the most important evaluations is the one about the work of Zoltán Szentkirályi, The Historic Categories of the Art of Space from 1967. It is interesting that it is inserted only as footnotes though its extent exceeds most of the others. Hajnóczi regards it as a work exposing philosophical depths built upon the contrast between the pairs of phenomena of space-time and space-mass applied slightly in a rigid way. Hajnóczi describes it as "witty in its own field" as the different historic periods are described as topographic - Ancient, eschatological - Medieval, intellectual - Early modern and $19^{\text {th }} \mathrm{c}$., rational - Modern/Contemporary, and the cyclical changing of these items as secondary determining elements within the periods: topographic and eschatological - Egypt and Mesopotamian, topographic and intellectual - Greek, topographic and rational - Roman architecture, eschatological and topographic - Byzantine, eschatological and intellectual - Romanesque, etc. But Hajnóczi regards this evolutionist determination as a rigid constraint. Finally, this evolution becomes exhausted in the end, reaching the contemporary era, and its crystal-like purity is blown up by the parallelism of the factors Though Hajnóczi admits this is absolved by the lack of historic vista. But, according to Hajnóczi, this theory also 
suffers the heavy heritage of the over-accentuation of the viewpoint with the primary role of mass in history.

All the mentioned scientists' work was summarised at the end:

"Both their starting points - thus as well as their results - are rather too general, and space is handled in a non-human context as objective facility. " 20

The works of practicing architects are introduced by Hajnóczi as the ones which were not able to mature as complete theories, but they are interesting, and they give more concrete explanations than those of theoretical scientists.

He might regard the attitude of Christian Norberg-Schulz as the closest relative to his way of thinking. The work most worth mentioning is owned by him, though he changed his opinion within one decade. This is the main advantage in his stature, because not the predetermined insisting on speculations and traditions will guide his thoughts but the continuous struggling and experience that certify his final results. Norberg-Schulz in his early work in 1963 (Intentions in Architecture) - seeing the multiplication of works dealing with theory of space - judged the enthusiasm too hot around this theme and he did not give an essential role to space in architecture. On the bases of his studies analysing the ongoing theories, he denies any kind of distinction between architectural and physical space, so his approach is much more abstract than the others'. But he highlights the objective abilities of surfaces and, by means of these, he can initiate the emerging of spatial relations. Hajnóczi has a similar category: the initiative-constructive agent - we can welcome its forerunner in the idea of Norberg-Schulz. We have no idea when these issues of this article from 1963 were learnt by Hajnóczi. What is certain is that he did not speak of it in 1967, but in 1974 in his article "Le Revizione del Concetto del Volume Architettonico", Hajnóczi introduces his nomenclature that was used in his dissertation for the membership in the Hungarian Academy of Sciences. There is another thing that was followed by Hajnóczi. Being a professor of architecture, Norberg-Schulz had carried out spaceexperiments with his students. For Hajnóczi, this method, which tends to be objective in exploring the genesis of space, is valuable. He also will carry on such experimentations at the beginning of the 1990s during the course of gathering data for his work (Genesis of Architectural Space). In his book in 1971 (Existence Space and Architecture) Norberg-Schulz has given back the role of architectural space that it deserves. He defines four different notions of space in the relation of humans from the concrete immediate space to the most abstract ones: activity, sensual, existential theoretical and abstract spaces. He analyses the existential space that is formed by different sensing processes. There are three layers of this notion: 1) centre and place, 2) direction and way, and 3) district and region. According to Hajnóczi, the greatest achievement of this work is that it criticises successfully the concept of modernistic flowing space - it is a good attempt to attack such misunderstood notions like the canon of floating, and flexibility. Hajnóczi entirely accepts the approach that the need for a constant - non-mobile - humanely structured environment is not an anachro-

${ }^{20}$ Hajnóczi 1977. 338. 
nism. Despite its abstractness in his theory, Norberg-Shulz did not identify architectural space - which is created by man - with mere physical environment. All these ideas echoed in the later works of Hajnóczi. According to Hajnóczi, the only deficiency in his work that he thought he had recognised was the need for an exact definition of architectural space, but he did not even attempt to fix it.

Hajnóczi had a positive approach to the thoughts of Robert Venturi (Complexity and Contradiction in Architecture, 1966). That belongs to the more practical approaches of space following the generalising and too abstract ideas of the first half of the $20^{\text {th }} \mathrm{c}$. Venturi says that architecture - according to its own nature - is complex, but we do not have to be afraid of it: we have to replace the program of "less is more" by the joy of "less is bore". His concept of space is the forerunner of the differentiated structures of Khan, and at the same time it contains a well-articulated system of spaces distinguishing the concept of useful and non-useful spaces, functionally primary and secondary spaces and also poché. This projects the richness of Hajnóczi's articulation in defining different kinds of spaces. The approach of Louis Kahn (Credo, 1974) was to subdivide the architectural space into intelligent particles according to its purpose and not just its function. He also denies the flowing space of modernism - for him only the properly delimited space is existing and flexibility can be interpreted within its borders. He also speaks about useful and service spaces in building and urban scale as well. According to Hajnóczi, his invaluable merit is that he regards architectural space as a human creation and not only physical space, and it determines our life, has an effect on our way of thinking. He also confessed to the essential role of the architect opposing the exclusive approaches initiated by either a technicist or behaviourist side.

The work of Yoshinobu Ashihara in 1970 (Exterior Design in Architecture) attempted the coordination of eastern and western tendencies. For Hajnóczi, the eastern culture is important since its space concept differs from that in western culture. For Hajnóczi, eastern culture is important as it has a different concept of space compared to the western concept: a western man focuses on objects whereas an eastern man can see the space in between objects, even giving a name for that: ma, which we can regard as the forerunner of Hajnóczi's intervallum. In connection with the exterior spaces he speaks of the factors determining non-covered spaces. This matter will fuel further the attendance of Hajnóczi in this direction. The metrical coordination of the pavement in Japanese architecture can be the model of Hajnóczi's pavimental definiteness. And also, in the case of Ashihara's centripetal and centrifugal spatial effect we can see Hajnóczi's disperse and conspers spatial relations. And there is an obvious parallelism between Ashihara's field of force (in between facing buildings) and Hajnóczi's spatial relations in Prolegomena. Also, the inner and outer corners of urban spaces and the categorization of spaces (inner, semi-inner, semi-outer, outer spaces) are all close relatives of the elements of Hajnóczi's system. Summarizing Ashihara's effect on Hajnóczi we can state that his basic point of view and the sprout of his basic approach is coming from this eastern culture. The workout and the analytic system are from the western school. 
In the field of the theoretical research of urban spaces the works of Kevin Lynch are related to Spatiology with their categories deriving from Gestalt-psychology. (Image of the City, 1960) But the similarities can be detected in methods rather than in particular elements.

There is only an indirect connection with the work of Christopher Alexander dealing with the theory of urban design (The City as a Mechanism for Sustaining Human Contact, 1966). That calls Hajnóczi's attention to social effects on spaces.

In the course of creating his grand theoretical system, Hajnóczi studies three other fields of sciences: Anthropology, Psychology (both Perceptual and Environmental) and Semiotics. The methodology of these sciences will help form the notions of spatial qualities. In the field of anthropology, he paid the most attention to the Proxemics (science of "keeping distances") work of E. T. Hall because of its practical approach. The difference between cultural backgrounds determining human needs regarding space is researched. Hajnóczi has considered the efficiency of the interdisciplinary method. The anthropological space of Hall (with its hidden dimensions) served as an important source in fixing the concepts of his spatial qualities. Hall calls Hajnóczi's attention to the sensual layers of space - that will be completed by him not just relying on the senses, and the importance of stability of spaces - fixed space (architecturally constant), partially fixed (architectural space with mobile furniture), and free spaces (evolving only between humans like: intimate, individual, corporate and public spaces). Hall proves for him the possibility of measuring the borders of layers of spaces by means of experiments. And there is a parallelism between Hall's sociofugal and sociopetal terms and Hajnóczi's inward and outward radiating space relations. And finally, he calls his attention to the reflections of consciousness on the perception process that make a kind of constancy in our relation to spaces, which were worked out by the psychologists. Even Hajnóczi notes that there are a lot of items in this theory that allow a real and profound insight into important aspects of space, but they were not rendered into a coherent system.

He learns a lot from psychology. Not just from its methodology but also its results. In the field of perceptual psychology the perceiving, sensing and understanding of space is in his focus in the works of W.H. Ittelson, K. Nagase, and D. Canter. David Canter's work in 1974 (Psychology for Architects) is dealing with special architectural questions. As a young branch of science it is troubled by the fight of different schools and approaches. Hajnóczi puts his foot down in this debate:

"I myself believe in finding the solution - meanwhile definitely not confessing myself the believer of physical determinism -, that we can assume the existence of essential forms of behaviour which are real, without any further differentiation as starting points, on the other hand architecture - as I underline again - is not a simple physical environment, but also inherited human form of behaviour beside many others, it is a behaviour: turned inside-out in the closest sense of the word." 21

${ }^{21}$ Hajnóczi 1977. 349. 
Though he was observing the first wing testing of the communication theories (semiotics or semiology) that was just unfolding at that time, no significant effect on his work can be shown.

\section{$* * *$}

Observing the enquiry of researchers from a lot of fields towards this topic, he finally confesses that the task of organizing a common system is waiting for the architects. His grand analytic system was intended to put the foundations of this work by means of fixing the basic notions. This is the Prolegomena to the Objective Evaluation of Architectural Creation - The Analytic Theory of Space - the dissertation of Hajnóczi Gyula for the membership of the Hungarian Academy of Sciences, which we can regard as his cardinal work in this field.

Its introduction, the research history was published separately in a periodical (Épités- Épitészettudomány) in the year of his dissertation. That was the evaluation of the works preceding Prolegomena and we have already presented their summary in the previous paragraphs. The diversity of the themes and the viewpoint drives Hajnóczi to make an attempt to integrate the cumulated information, there is a need to collect the results under a unified science. He announces the birth of Spatiology with a strong intention: "which [science] includes in some way our knowledge both about the interstellar and the personal space of humans."

Meanwhile, he does not deny the right for self-determination of particular sciences. That is why he speaks about astro-spatiology, physico-spatiology, psycho-spatiology, etc., or the urbano-spatiology and architectural-spatiology concerning architects.

He is dealing with Architectural Spatiology creating an analytic system: taking the space apart into elementary spatial relations and then he names them, evaluates them and describes the relations and the effects emerging between them, both with their quantitative and qualitative characters.

First he deals with the natural spatial relations. By means of them he creates his nomenclature and then he is dealing with architectural spatial relations. Parallel with natural formations, these relations are generated by structures bordering, supporting (i.e.: constructing) but meanwhile initiating different spatial relations of buildings. So these initiative-constructive agents will create different kinds of spaces. At the end he makes some proposals for the application of his theory.

The description of natural spatial relations starts with defining of the disperse and consperse character of positive and negative corners. These corners can be formed of similar and different surfaces. Between similar surfaces (both vertical and horizontal) the relations are homogeneous, and between the different surfaces (one is vertical, the other is horizontal) there are the heterogeneous relations. The positive corners have an outward radiation as the negative corners have an inward radiating effect. These effects can exist at the same place in the case of diverse terrain formations (river wall, pit, hill, etc.). Their mutual effect depends on their position in rela- 
tion to each other. If they are next to each other - their relation is peripheral, but they can be opposite to each other - in this case their connection is spatial. If the opposing surfaces are close enough to each other, the space between them is intensive, if they are far away, their space is extensive. Also, the human scale is inserted into the system by distinguishing the space that is accessible (and touchable) by humans - that is the fundamental space, and the one that is not accessible is the spherical. The spatial relations are existing with different intensity in different layers of space. He is dealing separately with the effect of the ceiling and the floor that can generate spatial images individually with their space effect. Finally, he states that even humans generate spatial relations around themselves which can penetrate onto the other ones (Fig. 2).

It is obvious that he does not speak of Euclid-type space but its articulation is based upon architectural aspects deriving from human factors. As the elementary spatial relations are determined by the effects of natural objects and terrain formations (initiative agents), the architectural ones are generated by the architectural structures. Their premier classification is based upon the circumstances of this initiative capability: what is their position within the building, and what is their space generator ability. In this way, the classification of these initiative-constructive agents (ICA) is also based upon architectural aspects. According to this, it is essential how many sides of a structure are facing exterior (so ICA is extensive) or interior (ICA is intensive) space, and what is their role - if they are separate spaces from each other (ICA is separative), if they are connecting them (ICA is conjunctive). According to

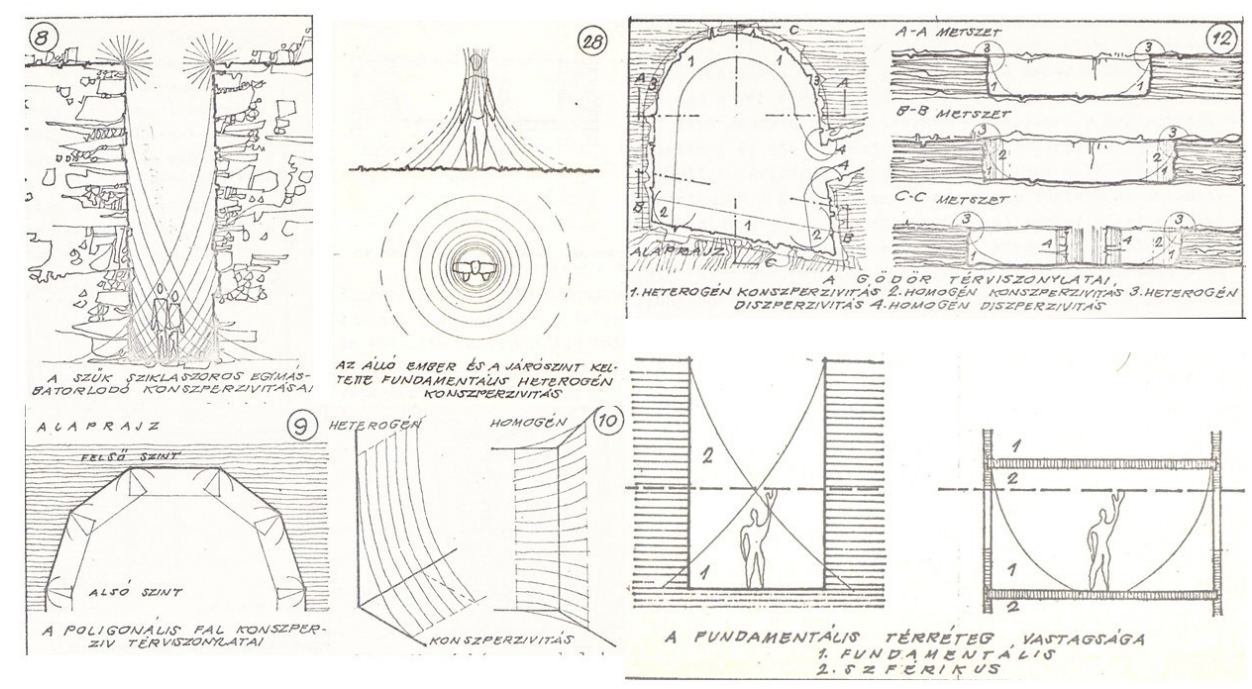

Figure 2. The illustrations of the natural spatial relations from the doctoral dissertation of Hajnóczi for the membership of the Hungarian Academy of Sciences from 1977. Source: Prolegomena to the Objective Evaluation of Architectural Creation - The Analytic Theory of Space. Manuscript. 1977. 

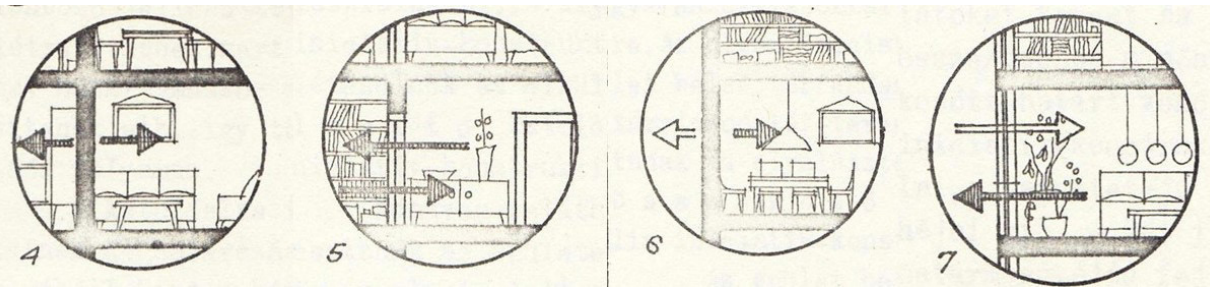

Figure 3. Classification of initiative-constructive agents (ICA) according to their spatial position and perforation from the doctoral dissertation of Hajnóczi for the membership of the Hungarian Academy of Sciences from 1977. 4. Intensive separative bilateral, 5. Intensive conjunctive bilateral, 6. Intensive/extensive separative bilateral, 7. Intensive/extensive conjunctive bilateral. Source: Prolegomena to the Objective Evaluation of Architectural Creation The Analytic Theory of Space. Manuscript. 1977.

all this, an external wall that has a window is an intensive/extensive bilateral conjunctive initiative-constructive agent. There is a separate category for the transparent agents. According to this 14 different ICAs can be distinguished. That is how these constructions can generate a great variety of classified spatial relations (Fig. 3).

The secondary classification can be carried out according to their constructive character. The viewpoints of this are based upon their material and structural behaviour, i.e. what the extent and method of human intervention in their creation was. According to this, these ICAs can be made of manipulated and non-manipulated materials and can be formed as structures which are non-manipulated or manipulated at a certain phase (pre-manipulated, during the construction or forcibly manipulated, etc.). Non-manipulated materials are stone, wood, brick, and manipulated are concrete and iron, which cannot be found in natural circumstances.

The determination of the quantities of space can follow their analytic classification. The space that has the largest volume is useful space (amplum space) enclosed by the structures. The closest vicinity of the structure bore the intervallum spaces, which are filling the gaps in between the structures. The subdivision of these spaces is provided by their human correspondence: fundamental and integral (as the parallel of spherical ones within a building). The interior and exterior spaces are also distinguished from each other and also if they are connected or not to each other. Finally, their covered or non-covered character is also important (Fig. 4).

In this way we have 14 initiative and 6 constructive determining factors for the initiative-constructive agents and in the case of spaces we have 35 different kinds of that. The quantitative analysis will provide the exact classification of particular buildings. Hajnóczi generated condensed drawings of the data to make the results more illustrative: like the drawings about the planimetrical and volumetrical characters proportioning the spaces and the structures to each other. As an expert of ancient history of architecture, he uses the Vitruvian classification of column orders for the buildings (Pykno-plan/cub, Syn-plan/cub, Eu-plan/cub, Dia-plan/cub and Araio$\mathrm{plan} / \mathrm{cub})$. 


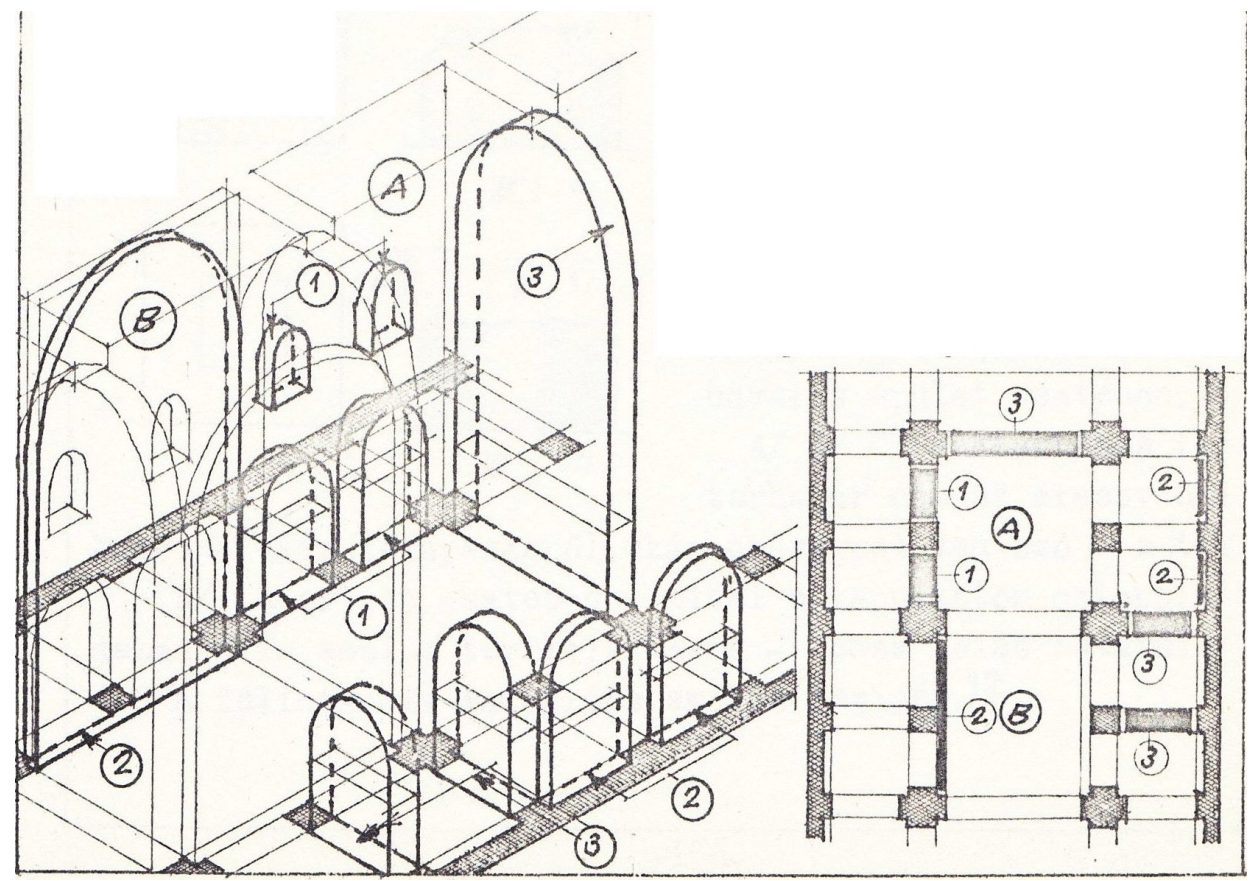

Figure 4. Classification of spaces inside a building from the doctoral dissertation of Hajnóczi for the membership of the Hungarian Academy of Sciences from 1977. 1. In-intervallum, 2. Peripheral intervallum, 3. Spatial intervallum. Source: Prolegomena to the Objective Evaluation of Architectural Creation - The Analytic Theory of Space. Manuscript. 1977.
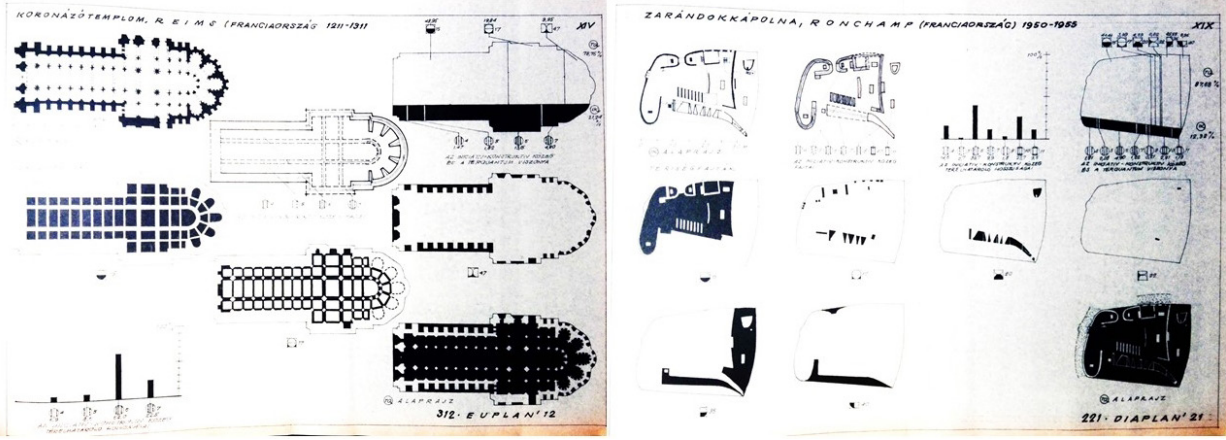

Figure 5. The quantitative analysis of spaces and masses (ICA-s) in the case of Reims Cathedral and the Ronchamp Chapel of Le Corbusier from the doctoral dissertation of Hajnóczi for the membership of the Hungarian Academy of Sciences from 1977.

Source: Prolegomena to the Objective Evaluation of Architectural CreationThe Analytic Theory of Space. Manuscript. 1977. 
Hajnóczi has carried out the analysis of several buildings in the course of historic times from ancient antiquity to modernism - keeping his prescribed rule always in mind: he has chosen numerous buildings which are relevant and characteristic in every period of time (Fig. 5).

This examination provided so much information that only a general analysis was carried out. He has answered 4 essential questions spanning the centuries: 1) what is the correlation between the structures and the quantum of space; 2) what is the intensive proportion of the created spaces; 3 ) what is the proportion between the amplum and intervallum spaces; 4 ) how is the proportion changing between the fundamental and integral spaces (Fig. 6).

The last chapter deals with the spatial qualities. He is testing the initiative-constructive agent's own spatial relations and their peripheral and spatial system of correspondences. It can be investigated according to four viewpoints: a) the peripheral spatial relations emerging from the construction, b) peripheral spatial relations deriving from the outline of the plan, c) the spatial relations deriving from the horizontal and vertical dimensions, d) how the realization of the architecture is carried out. For determining the intensity of spatial relations he uses human physiological perceptual abilities. Finally, he places even the human stature into the space as the relation generator agent and he highlights the parallelism of natural capability of a human stature to create temporary spaces as the result of the spatial behaviour (acute space) and the permanent space (chronic space) and the possible generating connection between the two. But we had to wait more than a decade for the articulation of that, which was the "Genesis of Architectural Space" (Az éptitészeti tér genezise).

In the end, Hajnóczi gave the possible ways of utilizing the theory. He sees this in the architectural design, in urban design, and also in architectural survey and registration. From the other side, the research can go on in the field of architectural psychology as an applied science of architecture. At that time digitalization and informatics were in its salad days, and he could hardly foresee the bright perspective of this development.

$* * *$

The oeuvre is closed by the Appendix, published as the Genesis of Architectural Space $^{22}$ (in Hungarian: Az épitészeti tér genezise). Hajnóczi gave a peculiar tone to this work. His poetic voice speaks up here that was hardly recognisable before. Each of his sentences are so keenly composed that they all could be single ars poetics, every one of them. He essentially wove the separate elements of the analytic system together again in order to let us see the birth of architectural space. It seems to be an effort to give the proof of that reality - what has been taken apart in the course of the analysis, can be put together again according to the logic of the genesis. Thus, it is not the simplification of his system, he did not formulate it to be easier to understand, nor translated its scientific language to a vulgar ordinary language of an architect.

\footnotetext{
${ }^{22}$ Hajnóczi 1992. Part I. 2.
} 

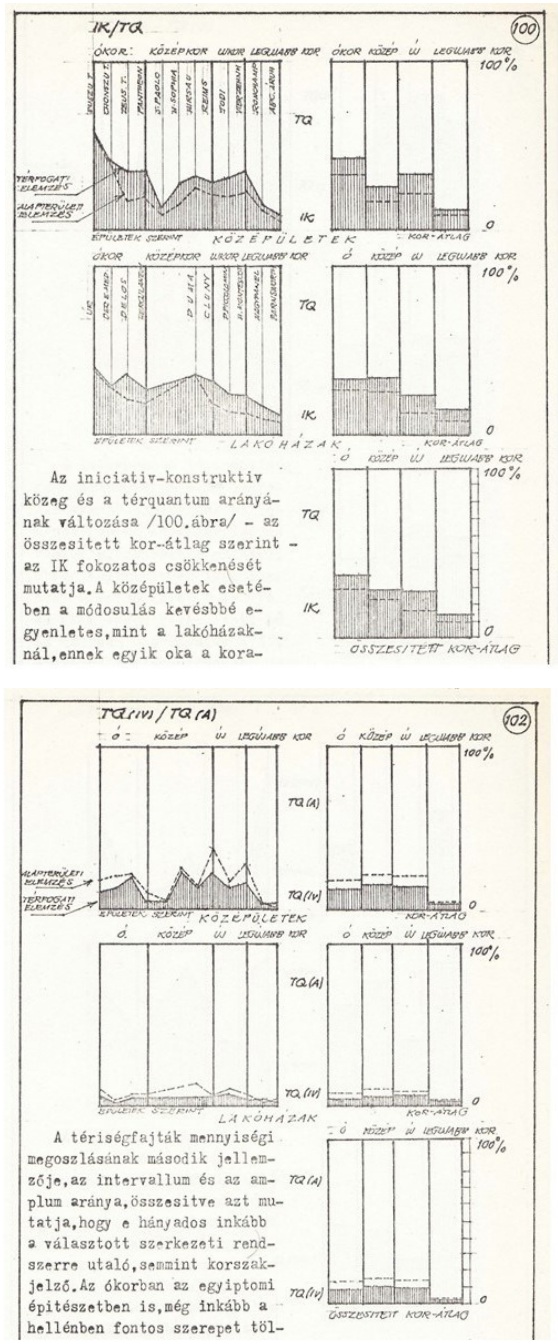
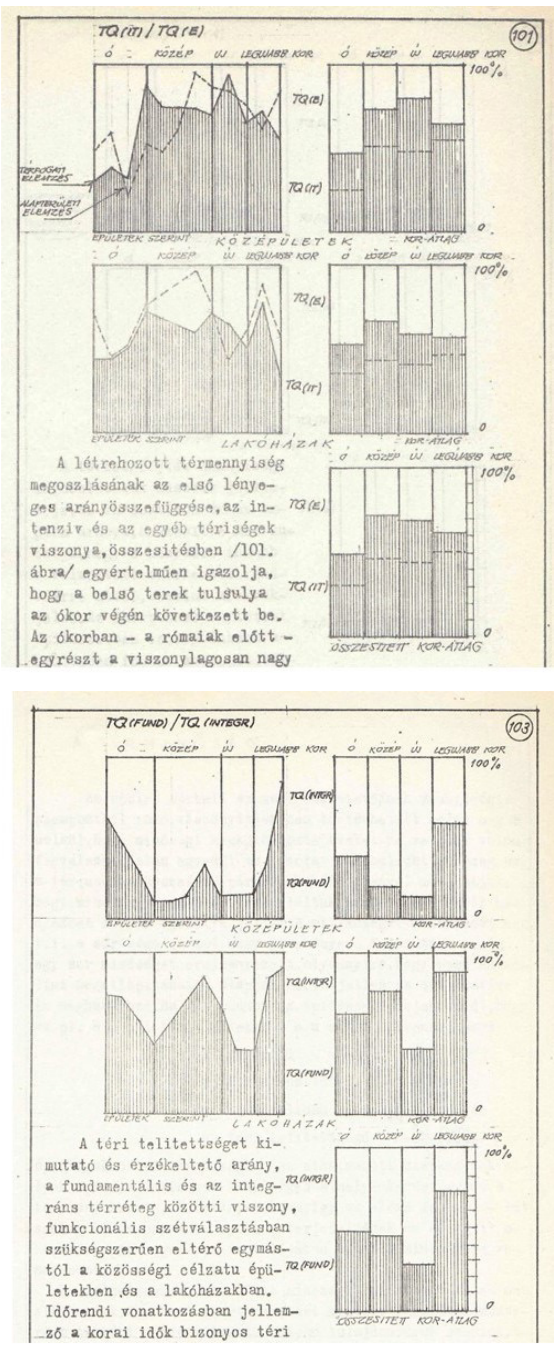

Figure 6 a-d. The summary of the quantitative analysis subdivided in different periods of time from the doctoral dissertation of Hajnóczi for the membership of the Hungarian Academy of Sciences from 1977. Fig. 100 shows the changing of the ratio between the mass and space during the periods of time

in the case of particular public buildings, dwelling houses and their averages, proving that the "efficiency" of the applied material in creating space was not increasing constantly. Fig. 101 shows the changing of the ratio between the intensive (interior) and other (exterior) spaces during the periods of time in the case of particular public buildings, dwelling houses and their averages. Fig. 102 shows the changing of the ratio between the amplum (usable) and intervallum spaces during the periods of time in the case of particular public buildings, dwelling houses and their averages, proving that the major factor determining it is not the time but the structure. Fig. 103 shows the changing of the ratio between the fundamental (touchable) and integral ("extra clearance") spaces during the periods of time in the case of particular public buildings, dwelling houses and their averages, proving that in medieval and Early Modern period we had more "spacious" (un-necessary) interiors. Source: Prolegomena to the Objective Evaluation of Architectural Creation - The Analytic Theory of Space. Manuscript. 1977. 
No. This is an approval, a demonstration that his system has always started from the human nature and it always returns back to it... Human beings are the living elements of his system, all humans are the creators of it: the creative human being. But it is nicer expressed in his words:

"What distinguishes the activity of a human builder from the instinctive construction of animals is that he not only creates a shelter for himself following his instincts, but also builds a home for his gods with faith and consciousness. Making use of the double meaning of the Latin word-aedes - which denotes both a dwelling house and a church, it can be simply and aptly illustrated that architecture is able to satisfy not only the material but also the spiritual needs of people. Human is a homo aedificator..."

And he also gives the resource of this creation: himself, his past and his environment:

"However, not only the spirit of the place, the genius loci, but also the spirit of the age, the genius aetatis, permeates the man-made work, so that it will eventually become a colour-changing mirror of the current worldview. ",23

"Thus, the built environment is not simply a physical environment, but an objectified form of human behaviour, a summary of life moments realized by the specific means of architecture. In which the Self and the community, the past and the present are summed up. If all this is true, then the question rightly arises: how the many things that dead material absorbed into itself when it came to life as a building were created ... All this can only be interpreted as something fundamental behavior embodied in architecture. The man is homo architectus. "24

The opus is subdivided into three theses:

For the first time we have to count all those physical-spiritual-intellectual factors that are determining the human perception of space. Parallel with this we have to unveil what kind of imaginations are driving humans in experiencing, interpreting and using spaces. For the second time the relationship of human and space can be experienced uncovering the characters of mainly changeable - mobile - space determined by equipment and furniture. For the third time we have to approach the relation between human and the "built up" - par excellence architectural - space.

He has found the obvious parallel of the genesis of architectural space in the genesis of human existence. He has built up the human concepts about space by means of the device systems of two branches of psychology: development psychology and perception psychology. Here Szentkirályi's evolutionism seems to dawn: as there the evolving and stages of historic categories of space are taking their parallel in accordance with the individual human development, here Hajnóczi is taking the same viewpoint articulating his thoughts in a poetic way:

"The fact that the womb is the first shell of our lives encourages further reflection, which requires a small intellectual bypass. A specific phenomenon accompanies the results of human culture: there are two poles that contradict but at the same time

\footnotetext{
${ }^{23}$ Hajnóczi 1992. Part I. 2.

${ }^{24}$ Hajnóczi 1992. Part I. 2-3.
} 
complement each other. ${ }^{25} \ldots$ This controversial relationship between object and space, which at the same time resolves their contradictions, leads to the conclusion that the object is the masculine, and the spatial quality is the feminine. Consequently, the essence of space is inherently something feminine, since it is the receiving medium that ensures existence ${ }^{26} . .$. Man receives the "first space« as a gift from the Creator, but the second is created by himself. ${ }^{27}$ " [As a positive mass/figure creating this space around himself.]

He calls the perception psychology for help to give the critic of the Euclidgeometry popular in modernist concept of space speaking about the human coordinate system. He makes a strong distinction between physical space and anthropomorphic (or anthropogenic) architectural space:

"Nevertheless, the vertical posture of man and the sense of balance that ensures this upright position play an important role in spatial perception and interpretation. This is because man carries within himself the 0 point of a coordinate system in which the vertical direction is dominant, thus, he considers all vertical lines and surfaces in his vicinity to be anthropomorphic and alive. In addition, the primary direction of movement of this unbalanced creature is »forward « - this is the second important axis in the system - and any rapid change of direction shifts him out of balance. Finally, man measures the distance and thus the space with his characteristic, stepby-step way of moving, similar to the way of determining the extent of objects with the dimensions of his body parts - elbows, palms, fingers, etc. "28

Humans can perceive space by means of their senses. Hajnóczi counts all of them and, as our theories of space were heading from items of material to spatial character deriving back to the tradition of Riegl, he builds his system alike, but never losing the sight of their role regarding space. Thus he determines 15 different kinds of space according to the channels of sensing from the most material to the most spatial (abstract): space of taste - saporal space, olfactory space - odoral space, space of touch - tactile space, muscle sensing space - muscular space, space of hearing auditive space, space of balance - equilibrium space, space of vision - visual space, space of colors - coloral space, space of shapes - formal space, space of movements - motional space (kinetic space), space of relocation - ambulative space (kinetic space), space of cognition or consciousness - mental space, space of recollection memorial or memory space, space of emotions or mood - affectual space, space of imagination - fantasy space, space of thought - cognitive space. This system may seem to be too complex, and some parts can be a little bit strange to be included: The space that can be tasted is an unusual approach, but for a little child it is natural, though it can hardly rise over the unconscious mind. But now we do not know if these elemental imprints into our minds have any effect on our behaviour. So, this is a sign

\footnotetext{
${ }^{25}$ Hajnóczi 1992. Part I. 7.

${ }^{26}$ Hajnóczi 1992. Part I. 7.

${ }^{27}$ Hajnóczi 1992. Part I. 8.

${ }^{28}$ Hajnóczi 1992. Part I. 9.
} 
that Hajnóczi does not allow for himself the superficiality of inconsistency. Therefore, this aspect should also be examined, but maybe not by architects. For me, the most impressing characteristic of this complexity is the subdivision of some basic sensual abilities: like vision. It highlights a lot of different kinds of information that we can perceive by means of our eyes: colours, forms and their movement on the screen of our retina. Also, the articulation of mental space calls the attention of the multilateral capability of how we can think about space: we can remember, we do have emotions, we can imagine and can think of spaces. I believe that there is a significant difference between these different aspects of perceptions: we do have different images of the space according to these approaches. Hajnóczi's summary in the introduction part of this chapter also evaluates them:

"The senses do not describe space with equal efficiency. However, one thing they have in common: that they capture not only the data provided by the environment, but also those coming from our bodies. Man is not only a 》self-conscious « but also a »self-perceiving « being. " 29

In supporting the right to exist of his analytic system, he creates an axiom - following the orders of the classical philosophy: the architectural space is form.

His verbal argumentation is always an intellectual experience. It is worth to show an example. However, he states that $80 \%$ of the data gained from perceiving originates from our vision, which is overwhelming. In giving the reasons of this distinction between colour-space, formal-space and movement-space he is very sophisticated. He talks about the atavistic connotations of colours on the bases of analogies and particular habits deriving from natural and social imprints. He regards the tone value (valeur) the most relevant, as it tells the most about the experienced spatial depth.

While speaking about vision of forms he speaks about our physiological and psychological experiences also resting on historical and natural analogies: "Shape perception is the basis of space perception. In reality, all the surfaces-lines-geometric shapes - and their relations - that populate the world of forms are keys to concretizing space. These create spatial elements from which the structure of space is built." 30

The third aspect of vision is the double face character of motion. He makes an important distinction between the real motion and the virtual motion - motion can be generated on our screen by the movement of the surrounding observed objects and also by the movement of the observer. These are the kinetic and ambulative spaces. Finally, he makes a profound statement about these processes. As the perception is a complex and parallel process, it is hard to pick one of them to analyse it separately from the others. The effects are not independent from each other:

"It is hard to separate the factors involved in the total perception process because man is immersed in this whole at once. Yet, in addition to acknowledging the existence of spatial boundaries that create space, an attempt should be made to discover

\footnotetext{
${ }^{29}$ Hajnóczi 1992. Part II. 10.

${ }^{30}$ Hajnóczi 1992. Part II. 17.
} 
whether these existing features are capable of exerting effects that are more objective than other factors. And this is only possible by analysing form itself." 31

The third chapter is about the real genesis of space. This is the point where he binds together the parts that were taken apart from each other in order to analyse them, to make an intelligent whole again. The new element is that he makes an interesting connection between the qualities and quantities of space. He interprets different layers of space, and from that understanding, he deduces the space creating capabilities of structures. He denotes the essential role of the vertical space delimiting element from the primary character of fundamental space, and parallel with it, he states the secondary role of space-coverings. In order to prove his statements he made space-experiments with students of architecture.

"Humans are pavement living creatures... It would be a bold assumption to say that there was some magical force flowing from the side boundary, and that something like "surface attraction" works. ... Where the row of peripheral spatial elements loses its strength and dies, there is the zone where the spatial field begins to extend and spread, which is more airy and rarer than the one by the wall. Thus, in the structure of the enclosed space, the form-induced peripheral row of elements embraces the spatial field created by the spatial elements." ${ }_{32}$

The final classification of the elementary spatial relations results only in five different types: three bay-like (concave - inner corner) and two massive (convex - outer corner). These are interwoven with the horizontally extending layers of the space and this texture is the construction of space.

The boundaries between the particular regions of space (the parameters of the changing of this tissue) are very characteristic to the space. The on-field experiments carried out by students aimed to clarify the metrical parameters of these borders. These also attempted to clarify not only the distances but also the qualities of space. The experiments took place at the ramparts of the Buda Castle and in the great hall of the University. In the case of the outside experiments, spatial relations were created by the ramparts and the field around. Hajnóczi wanted to determine the typical distances between these invisible borders and on top of this he made an attempt to clarify the nature of the cognitive space by means of interviews with the students. The existence of these borders within the actual space in front of the great wall were proved and their position was determined. During the interviews the answers contained experiences regarding ambulative, tactile, muscular, memorial, imaginary and cognitive spaces. These experiments proved obviously the initiation of the unfolding of these "structural elements" of the space.

In the course of the experiments in the great hall of the University there were neutral wooden screens arranged to form particular elementary spaces. The aim was to test the interaction of peripheral spatial relations. Hajnóczi determined three elementary cases:

\footnotetext{
${ }^{31}$ Hajnóczi 1992. Part II. 21.

32 Hajnóczi 1992. Part III. 23.
} 
1) The spatial (circular) space is objectified in a harmonious way. The circle is a space-like space. Hajnóczi gives the reason for this statement: the "European way of thinking is rooted in the ancient Hellenic philosophy, and the approach to space in an intellectual way is also the merit of Hellenism. ${ }^{\text {"33 }}$ It initiates the spatial relations in an invisible, implicit way.

2) The sectioned (sequential) spaces are the even polygonal ones. They are in an intermediate stage between the circular and rectangular (right-angled) spaces. They are very close in character to circular spaces as both of them are formed in a way radiating with an equal extent from a vertical axis. The only difference is that in the case of regular polygons the bordering walls are changing their direction in a sequential order with slight brakes, whereas in the case of circular walls this border coalesces.

What I feel to be a really eye-opening thought at the end of the analysis of the first two items is the aspect of unfolding of the space - the problem of entering into these spaces. This is where we can observe the real complex viewpoint of Hajnóczi. At the same time, it is a perfect example to prove that the physical space or the Euclideanspace is not identical with the architectural space at all. The meaning of architectural space must be filled with architectural aspects, like: where is the entrance? He states that the spatial effect changes at once if we open a doorway somewhere on a circular (or circular-like) wall. The neutral space that has only one axis: vertical, will get also a horizontal one at once - polarizing the space horizontally. So, the perfectness of these harmoniously objectivated spaces can be preserved by means of opening a gate right in the centre of this space and we can come from the vertical direction. (If we add to all this the frontal receptors of humans - that our eyes are determining the axial character of the human perception we can forget this perfectness...) Hajnóczi, the expert and lover of ancient architecture was focused on antic examples. We can widen the perspective to further periods of time, how medieval architects tried to solve the problem of preserving this perfectness. Within the paradigm of the additive space constructions in antiquity, the solution to that problem is not possible - only in that axial unfolding in the vertical direction. The Early Christian period have had to change this paradigm - turning the space constructions to be conjunctive - how the central space of the rotunda of Santa Costanza is bordered by a row of (double) columns, integrating the ambulatory space into the central one harmoniously. The continuous circular wall is substituted by a continuous effect of the row of columns, providing a continuity of entering possibilities from almost all directions. From the scientific point of view, the two spatial situations are not the same - but from the aspect of preserving perfectness, this is an identically right solution.

On the other hand, Hajnóczi calls the attention to the importance of the unfolding of spaces. We can reinforce his opinion again with an example from medieval times. It is well-known that the antique roman architecture was not sensitive to function-specific forming - we certainly cannot determine the function of a building solely on the

\footnotetext{
${ }^{33}$ Hajnóczi 1992. Part IV. 35.
} 
bases of its form. It is enough to recall the awkward changing of scientific results of the "serapheum" in Pozzuoli (Italy, Naples) when at the early stage of the archaeological research the findings were determined as the sanctuary of the God Seraphis - as a corresponding statue was found nearby. Later it turned out that it was simply a meat market (or butchery). The same phenomenon is the lot of possible uses of basilicas. In Roman times these spaces were used for different purposes: a throne hall for emperors, a meeting room for the public, a courthouse, or a department store. Their common feature was their general unfolding: transversal - in most cases we can enter an antique basilica at the transversal axis so the internal space is unfolding laterally. Also, Early Christians used the basilica-form for their own purposes - but in this case the entering point became fixed along the longitudinal axis. Only just changing the unfolding of the space they changed the meaning of it: an ordinary public building became a Christian temple with a meaningful longitudinal procession.

3) The cornered (rectangular) space is the third and the most general of all as an architectural space. It is thought-provoking that the origin and spreading of right-angled spaces has been obscured until today, and science still owes a clear explanation of its evolution. Yet, we are living in spaces like this day by day, and it can be stated without any exact statistical data that this is the most frequent type of space in the architecture of the world. Hajnóczi dares to shape a cautious explanation in this question. However, he shows the correspondence between the construction material and the form of space (the plano-convex bricks were used for curved walls, whereas the square ones were used for rectangular buildings in ancient Mesopotamian world) but he underlines the importance of other human factors:

"... here we can rightly refer to the verticality of the human physique, our right and left hands, the primarily horizontal nature of our field of vision, and the primary and involuntary forward direction of our movement. If the assumption that man projects this coordinate system onto his environment is true, then it automatically follows that the right angle, either way, is a human geometric shape. The right angle means a man-made order. When mentioning the Roman city, the other (earlier) classical culture, the Hellenistic urban pattern should be considered too, namely the siting according to an orthogonal grid of streets. Aristotle writes the following about this: "The arrangement of the private dwellings is thought to be more agreeable and more convenient for general purposes if they are laid out in straight streets, after the modern fashion, that is, the one introduced by Hippodamus; but it is more suitable for security in war if it is on the contrary plan, as cities used to be in ancient times; for that arrangement is difficult for foreign troops to enter and to find their way about in when attacking. Hence it is well to combine the advantages of both plans (for this is possible if the houses are laid out in the way which among the farmers some people call 'on the slant' in the case of vines), and not to lay out the whole city in straight streets, but only certain parts and districts, for in this way it will combine security with beauty. "”34

34 Hajnóczi 1992. Part IV. 38. 
Only the three elemental spatial relations were described finally by Hajnóczi. From a geometrical analysis it turned out that the circumference of the circle is the shortest, thus it needs the minimum amount of material to construct it - so this is also the most areal type of space. Moreover, the peripheral relations only existing in a latent way result in the largest spatial spaces. On the contrary: in the case of largely stretched rectangular spaces the space within is more solid, as the denser peripheral relations are emerging here... The row of thoughts is braking here. There was not enough time to articulate the more complex space types. The thoughts written down afterwards might be regarded as his testament in the field of theory of space: "The morphological reality of the entire enclosure needs to be elaborated in more detail. After all, this study was just about the basic types. Variants of these, the different outlooks, the articulation of the delimiting surfaces, the many variations of the spatial separation are theoretically elaborated, but they are waiting for experimental confirmation. Topping the space from above further complicates the issue, because the roofing can harmonize with the shape of the spatial perimeter (hemispherical domed rotunda, polygon with ribbed dome, oblong rectangle with flat ceiling), but it can also be of a different nature (circular space with flat roof, square covered with a ribbed dome, or a rectangular space with vault). And the multitude of other spaces and their modes of spatial connection complete all this. Even if the assumption is true that many human thoughts, gestures, and behavioural elements have already manifested in these spaces, they are still made alive by those who live in them, who inhabit, furnish, and use these spaces. Only the exploration and nuanced interpretation of the »secrets « of the installed and ephemeral space makes the chronic (architecturally shaped) space real. ",35

... The oeuvre is complete, the research is unfinished. The framework is existing, it just needs filling in with human content. The vocabulary and grammar of the Science of Spatiology have been born, we should speak this language either in a binary or an analogue way. This is our responsibility thenceforth...

${ }^{35}$ Hajnóczi 1992. Part IV. 63. 


\section{A SPACIOLÓGIA GENEZISE}

\section{HAJNÓCZI GYULA ÉPÍTÉSZETI TÉRREL FOGLALKOZÓ MUNKÁI}

\section{Összefoglaló}

A tér építészeti értelmezésének megalapozását az európai kultúrában már a görög bölcseletben megleljük. A püthegóreusok számok közötti ürességétől (kenon) az építészeti tér Szt. Ágoston általi meghatározásáig tart a folyamat, melyben végül az építészet legfőbb feladataként a tér alakítását határozták meg. Ezen értelmezések körüli érdeklődés felizzott a második világháborút követő időben - ebbe a diskurzusba kapcsolódott be Hajnóczi Gyula térelméleti munkássága az 1960-as években. Azzal a szándékkal lépett fel, hogy egységes keretet adjon a sok tudományág felöl érkező építészeti tér-értelmezéseknek. Ez a közös értelmezési tartomány a tér analitikus értelmezéséből sarjad - ezt a tértudományt nevezte el spaciológiának. Végigtekintve Hajnóczi Gyula térelméleti műveit igyekszünk bemutatni a gondolatok kifejlődésének folyamatát, valamint kísérletet teszünk arra, hogy felmutassuk a kortárs kutatók munkásságában Hajnóczi Gyula gondolati rendszerének előzményeit. Az 1977-ben megjelent akadémiai doktori értekezésében az építészeti tér analitikus értelmezésével szétbontotta az építészeti teret az azt meghatározó konstruktív közegek elemi térviszonylataira, és ezek mennyiségi és minőségi értelmezését kísérelte meg. Az életmü végső akkordjaként írt, Az épitészeti tér genezise c. müve az analitikusan szétbontott és egyenként értelmezett térelemek rendszerének megértésére, az elemek újbóli összeépítésére tett kísérletet.

Kulcsszavak: Hajnóczi Gyula, építészetelmélet, térelmélet, spaciológia, genezis

Open Access statement. This is an open-access article distributed under the terms of the Creative Commons Attribution 4.0 International License (https://creativecommons.org/licenses/by/4.0/), which permits unrestricted use, distribution, and reproduction in any medium, provided the original author and source are credited, a link to the CC License is provided, and changes - if any - are indicated. (SID_1)

Received: 10 December 2020. Accepted: 12 December 2020

First published online: 22 February 2021 